\title{
Quantification of the genetic change in the transition of Rhodnius pallescens Barber, 1932 (Hemiptera: Reduviidae) from field to laboratory
}

\author{
Leysa Jackeline Gómez-Sucerquia, Omar Triana-Chávez, Nicolás Jaramillo-Ocampo/+ \\ Grupo Biología y Control de Enfermedades Infecciosas, Instituto de Biología, Universidad de Antioquia, Sede de Investigación \\ Universitaria, Calle 62 52-59, Medellín, Colombia
}

\begin{abstract}
Previous studies have reported genetic differences between wild-caught sylvatic, domestic and laboratory populations of several Triatominae species. The differences between sylvatic and laboratory colonies parallel are similar to the differences observed between sylvatic and domestic populations. Laboratory colonies are frequently used as references for field populations, but the consequences of founder events on the genetic makeup of laboratory or domestic populations are rarely quantified. Our goal was to quantify the genetic change in Rhodnius pallescens populations artificially submitted to founder effects via laboratory colonization. We compared the genetic makeup of two sylvatic populations and their laboratory descendants using a panel of 10 microsatellite markers. Both sylvatic populations were initially collected from palm trees, but the colonies differed in the number of founder insects and amount of time kept in the laboratory. We evaluated allelic polymorphism, differences between expected and observed heterozygosity, estimates of population differentiation $\left(\mathrm{F}_{s}\right)$ and inbreeding $\left(\mathrm{F}_{i s}, \mathrm{~F}_{i}\right)$ and cluster analyses based on Nei's distances. We found a unique genetic structure for each sample population, with significant differentiation between the field insects and each of the laboratory generations. These analyses showed strong founder effects and showed that genetic drift had led to a genetic equilibrium over several generations of isolation. Our results suggest that laboratory colonies of $\mathrm{R}$. pallescens have a different genetic structure than their wild relatives and similar processes likely affect other Triatominae laboratory stocks.
\end{abstract}

Key words: Rhodnius pallescens - microsatellites - laboratory colonies - population genetics

Rhodnius pallescens is considered a secondary vector of Trypanosoma cruzi (the causative agent of Chagas disease) in Colombia due to its high rate of natural infection, its ability to defecate during feeding and the closeness of the primary habitat of the species (palm trees) to human dwellings (Jaramillo et al. 2000, Guhl et al. 2007). These insects are found in houses in Panama, Nicaragua and Costa Rica (Sousa 2002, Calzada et al. 2006, Zeledón et al. 2006), where vector-human contact is likely to increase (Calzada et al. 2006, Zeledón et al. 2006). The insect is frequently found in houses in Colombia, although colonies established inside of houses, known as house colonies, are rare (Jaramillo et al. 2009).

Two major processes occur during domestication: a founder effect followed by a population expansion leading to intraspecific competition. If a newly founded population is isolated from its sylvatic congeners, genetic diversity is restricted and the diversity of the isolated population decreases (Dujardin 1998, Schofield et al. 1999). Therefore, when house colonies are established these restrictions cause genetic drift with a consequent loss of

Financial support: CODI, Universidad de Antioquia (CPT-0604 and programa de sostenibilidad 2007-2008)

+ Corresponding author: nicolas.jaramillo@siu.udea.edu.co

Received 16 February 2009

Accepted 26 August 2009 allelic variability, which may make the isolated colony genetically distinct from the wild population from which it originated (Dujardin 1998, Schofield et al. 1999).

During the transition from sylvatic to domestic or laboratory environments, a loss of genetic variability has been observed in several triatomine species, as measured by isoenzymes (Lopez \& Moreno 1995, Chavez et al. 1999) and random amplified polymorphic DNA (Borges et al. 2005). In addition, morphological changes have been detected in these colonies, including significant reductions in average body, head and wing size, the degree of sexual dimorphism, relaxation of bilateral symmetry and differences in the antennal sensilla patterns (Schofield 1994, Dujardin et al. 1997a, b, 1999a, b, c, d, Dujardin 1998, Schofield et al. 1999, Jaramillo et al. 2002, Catalá et al. 2004). Thus, differences between field and laboratory colonies could parallel those between sylvatic and synanthropic populations (Caro-Riaño et al. 2009).

The present study assessed genetic changes caused by founder effects during the establishment of laboratory colonies of $R$. pallescens. We compared variability of 10 microsatellite loci in two sylvatic palm tree populations and their laboratory descendants. Laboratory colonies differed in the number of founders as well as the amount of time maintained in the laboratory. We expected a loss of genetic variability due to the effects of "sampling error" (Dlugosh \& Parker 2008), i.e., the stochastic processes associated with founder effects following the invasion of a new habitat by a few individuals from a well-established population. 


\section{MATERIALS AND METHODS}

The insects - This study involved $R$. pallescens adults from two field populations and four laboratory colonies. We examined a total of 26 insects collected in Attalea butyracea palm trees from the municipality of San Onofre, Colombia (SO-P $40 \mathrm{~m}$ asl; 09²4 $4^{\prime 2} 9^{\prime \prime} \mathrm{N}$ $75^{\circ} 31^{\prime} 20^{\prime \prime} \mathrm{W}$; tropical dry forest, mean temperature of $28^{\circ} \mathrm{C}$ ), 10 1st-generation offspring from a laboratory population (SO-1) and 36 10th and 11th-generation individuals from laboratory populations (SO-11). We also collected five insects from A. butyracea palm trees in the municipality of Norcasia, Colombia (N-P 237 m asl; $05^{\circ} 20^{\prime} 24^{\prime \prime} \mathrm{N} 74^{\circ} 31^{\prime} 39^{\prime \prime} \mathrm{W}$; tropical wet forest, mean temperature of $\left.26^{\circ} \mathrm{C}\right), 19$ 1st-generation laboratory offspring of these wild-collected individuals (N-1) and 29 7th and 8th generation individuals (N-8). The San Onofre laboratory colony was founded in 1999 with 190 specimens and the Norcasia laboratory colony was founded in 2002 with eight specimens. The number of generations under laboratory conditions was calculated using average generation time of two generations per year (Jurberg \& Rangel 1984). All insects were maintained under controlled temperature and humidity $\left(27 \pm 2^{\circ} \mathrm{C}\right.$ and $\left.60 \pm 5 \% \mathrm{RH}\right)$ and fed weekly on chickens.

DNA extraction - DNA was extracted from legs of each insect using the salting out method described by Miller et al. (1988). DNA was evaluated in $1 \%$ agarose gels stained with ethidium bromide, quantified by spectrophotometry and stored at $-20^{\circ} \mathrm{C}$ until amplification.

Amplification of microsatellite markers - We used ten previously described microsatellite markers (L3, L9, L13, L17, L25, L33, L43, L47, L50, L58) specific to R. pallescens (Harry et al. 1998). These markers were amplified through PCR with a final volume of $12.5 \mu \mathrm{L}$. PCRs contained $20 \mathrm{ng}$ template DNA, $50 \mathrm{mM} \mathrm{KCl}, 10$ $\mathrm{mM}$ Tris- $\mathrm{HCl}, 0.1 \%$ Triton X-100, $1.5 \mathrm{mM} \mathrm{MgCl}, 12.5$ pmol of each primer (with fluorescently labelled forward primers), $200 \mu \mathrm{M}$ dNTPs and $0.625 \mathrm{U}$ of Taq DNA polymerase. Amplifications were performed in a PTC- $100^{\mathrm{TM}}$ thermocycler (MJ Research, Inc), following the thermal profile described by Harry et al. (1998).

After amplification, $1 \mu \mathrm{L}$ of PCR product was mixed with $13 \mu \mathrm{L}$ of deionized formamide plus $0.1 \mu \mathrm{L}$ of standard weight marker and this mixture was analysed on an ABI Prism MT310 Genetic Analyzer (Perkin-Elmer). Genotypes were read using GeneMapper ${ }^{\mathrm{TM}}$ version 4.0 (Applied Biosystems, Foster City, CA, USA).

Data analysis - The genetic variation was evaluated at ecological and geographical levels. The ecological level included comparisons between each field population and its laboratory offspring, while the geographical level considered differences between the two regions San Onofre and Norcasia.

Genetic variability was estimated through the proportion of polymorphic loci, number of alleles per locus, the mean number of alleles per sample and the heterozygosity. The observed heterozygosity was compared to expected heterozygosity under HardyWeinberg equilibrium using Fisher's exact test (Fisher
1922). Significant differences were corrected using Bonferroni's method (Holm 1979). Linkage disequilibrium between loci was evaluated with Fisher's exact test (Fisher 1922) and values were adjusted using Bonferroni's method (Holm 1979).

Genetic differentiation was evaluated by estimating Wright's F-statistics according to Weir and Cockerham (1984). These statistics allowed us to quantify reproductive isolation between populations and colonies $\left(F_{\mathrm{st}}\right)$ and levels of inbreeding both within populations and colonies $\left(F_{\mathrm{is}}\right)$ and within the metapopulation without considering subpopulations $\left(F_{\mathrm{it}}\right)$. Statistical significance of the F-statistics was assessed by bootstrapping 1,000 replications. $F_{\text {st }}$ was also used to estimate gene flow $(\mathrm{Nm})$ between samples according to Barton and Slatkin (1986).

A matrix of unbiased genetic distances was calculated using the Nei (1978) method and this matrix was used to construct an unweighted pair group method with arithmetic mean dendrogram.

All calculations were computed using GDA 1.0 (Lewis \& Zaykin 2001), Genepop 3.1-3.4 (Raymond \& Rousset 1995) and GenAlEx 6 (Peakall \& Smouse 2006) software.

\section{RESULTS}

All loci were polymorphic in each population, with the exception of loci L33 and L47, which were monomorphic in N-P and L33 in N-1 (Table I). In general, the three Norcasia samples showed fewer alleles per locus than those from San Onofre. Moreover, the number of alleles identified from SO-1 and SO-11 was lower the number identified from SO-P. The Norcasia laboratory population did not show a decreased number of alleles relative to their wild counterpart populations (Table I).

The three Norcasia samples showed lower heterozygosity than the San Onofre samples (Table I). However, SO-P and SO-1 showed the greatest deficit of heterozygosity. All populations were in Hardy-Weinberg equilibrium for the most part, except N-8, in which seven of the 10 loci in H-W disequilibrium (Table II). Fisher's exact test did not reveal significant linkage disequilibrium within any population $(\mathrm{p}>0.05)$.

The F statistics showed significant subdivision between populations in each region (Norcasia and San Onofre), except between SO-P and SO-1 (Table III). The metapopulation also showed significant structuring $(F$ : 0.2045 , CI: $0.2661-0.1450)$, as did the wild SO-P and N-P populations $\left(F_{\mathrm{st}}: 0.2296\right.$, CI: $\left.0.3277-0.1330\right)$. The number of migrants per generation $(\mathrm{Nm})$ between these two regions was calculated to be 0.83 , which indicates roughly four migrants every five generations.

The metapopulation presented a significant amount of inbreeding $\left(F_{\mathrm{it}}: 0.3123\right.$, CI: 0.4121-0.2051). Similarly, inbreeding within both the Norcasia and San Onofre populations $\left(F_{\mathrm{i}:}: 0.1853, \mathrm{CI}: 0.3371-0.0039\right.$ and $F_{\text {it }}: 0.2020$, CI: 0.2999-0.0794, respectively).

The amount of inbreeding within samples was significant $\left(F_{\text {is }}: 0.1355\right.$, CI: $\left.0.2359-0.0185\right)$. Similar results were seen for the San Onofre population $\left(F_{\text {is }}\right.$ $=0.1445$, CI: 0.2433-0.0369), but inbreeding was not detected within the Norcasia population $\left(F_{\text {is }}=0.1206\right.$, CI: 0.2905 to -0.0749 ). 
The dendrogram (Figure) constructed from the Nei's distances matrix showed two distinct groups: one composed of the San Onofre samples and the other composed of the Norcasia samples. In the San Onofre group, SO-P and SO-1 were closer than SO-11. In the Norcasia group, $\mathrm{N}-1$ and N-8 were more similar to each other than to N-P (Figure).
The San Onofre laboratory colony (SO-11) was founded with 190 individuals and, at the time of the analyses, between 10-11 generations had already reproduced under laboratory conditions. This artificial colony was in Hardy-Weinberg equilibrium, but differed genetically from the original wild population (SO-P). Table I

TABLE I

Quantification of genetic change in Rhodnius pallescens populations artificially submitted to founder effects

\begin{tabular}{|c|c|c|c|c|c|c|c|}
\hline \multirow[b]{2}{*}{ Locus } & \multicolumn{7}{|c|}{ Sample } \\
\hline & $\begin{array}{l}\text { SO-P } \\
n=26\end{array}$ & $\begin{array}{c}\mathrm{SO}-1 \\
\mathrm{n}=10\end{array}$ & $\begin{array}{l}\mathrm{SO}-11 \\
\mathrm{n}=36\end{array}$ & $\begin{array}{l}\text { N-P } \\
n=5\end{array}$ & $\begin{array}{c}\mathrm{N}-1 \\
\mathrm{n}=19\end{array}$ & $\begin{array}{c}\mathrm{N}-8 \\
\mathrm{n}=29\end{array}$ & $\begin{array}{c}\text { Total } \\
\mathrm{n}=125\end{array}$ \\
\hline L3 & 9 & 7 & 8 & 5 & 6 & 9 & 20 \\
\hline L9 & 6 & 6 & 4 & 3 & 3 & 6 & 10 \\
\hline L13 & 5 & 5 & 4 & 2 & 6 & 4 & 11 \\
\hline L17 & 22 & 5 & 7 & 3 & 4 & 2 & 25 \\
\hline L25 & 4 & 3 & 4 & 2 & 4 & 5 & 6 \\
\hline L33 & 7 & 6 & 9 & 1 & 1 & 3 & 12 \\
\hline L43 & 9 & 7 & 6 & 3 & 3 & 5 & 12 \\
\hline L47 & 3 & 2 & 3 & 1 & 5 & 4 & 7 \\
\hline L50 & 14 & 10 & 11 & 5 & 5 & 6 & 28 \\
\hline L58 & 7 & 5 & 7 & 2 & 4 & 3 & 11 \\
\hline Mean & 8.6 & 5.6 & 6.3 & 2.7 & 4.1 & 4.7 & 14.2 \\
\hline $\mathrm{He}$ & 0.747 & 0.711 & 0.632 & 0.374 & 0.535 & 0.519 & 0.733 \\
\hline Но & 0.596 & 0.535 & 0.593 & 0.345 & 0.464 & 0.462 & 0.528 \\
\hline Difference & 0.151 & 0.176 & 0.039 & 0.029 & 0.071 & 0.057 & 0.205 \\
\hline
\end{tabular}

the variability of 10 microsatellite loci is shown as the allele number per locus and the mean allele number per sample. He: expected heterozygosity; Ho: observed heterozygosity; n: sample size; N-P: parental (sylvatic) Norcasia; N-1: 1st-generation filial Norcasia; N-8: 7th-8th-generation filial Norcasia; SO-P: parental (sylvatic) San Onofre; SO-1: 1st-generation filial San Onofre; SO-11: 10th-11th-generation filial San Onofre.

\section{DISCUSSION}

Colombian $R$. pallescens populations are highly homogeneous, with little genetic variability (Lopez \& Moreno 1995). However, the present study detected a mean of 14.2 alleles per locus. This is a higher value than reported by Harry et al. (1998), who found a mean of nine alleles per locus in insects within the San Onofre municipality. Partial sequences of the mitochondrial $C y t$ $b$ gene (663 bp) exhibit high genetic variability and four haplotypes were found in nine $R$. pallescens individuals (Abad-Franch 2003). High chromosomal variability was detected in this species using the C-banding technique that characterizes differences in amount, size and distribution of constitutive heterochromatic regions in the chromosome complement (Gómez-Palacio et al. 2008). The 10 loci identified in our study each showed linkage equilibrium, validating DNA microsatellites as an independent marker system useful in observing genetic variation occurring in the transition between a natural and an artificial (laboratory) environment. shows that SO-11 possesses fewer alleles than does SO-P and also shows a different distribution in the number of alleles per locus. The Norcasia laboratory colony (N-8) was founded with only eight insects and had undertaken between 7-8 laboratory generations at the time of this study. Contrasting with SO-11, the N-8 sample was not in Hardy-Weinberg equilibrium (Table II).

A cluster analysis showed that there was greater allelic similarity between SO-P-SO-1 than SO-11 and more allelic similarity between N-1-N-8 than N-P (Figure). These results may reflect differing histories of each population under laboratory conditions (San Onofre vs. Norcasia). The longer laboratory history of the San Onofre colony has likely allowed accumulation of more differences than found in the Norcasia colony. Overall, the Norcasia colony showed the effects of a small founding population and a short period under laboratory conditions compared with San Onofre.

$F_{\text {st }}$ analyses (Table III) revealed significant population subdivision, likely reflecting the physical and temporal separation of laboratory individuals from field 


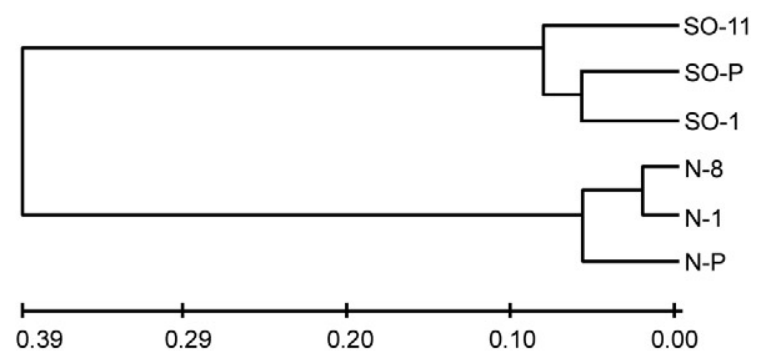

Dendrogram constructed using the unweighted pair group method with arithmetic mean method from Nei's genetic distances matrix. N-P: parental (sylvatic) Norcasia; N-1: 1st-generation filial Norcasia; N-8: 7th-8th-generation filial Norcasia; SO-P: parental (sylvatic) San Onofre; SO-1: 1st-generation filial San Onofre; SO-11: 10th-11th-generation filial San Onofre.

populations. $F_{\text {st }}$ was significant between SO-P-N-P, reflecting the geographic distance of more than $450 \mathrm{~km}$ between San Onofre and Norcasia. Interestingly, there was no subdivision detected between SO-P-SO-1 (Table III) in spite of small sample size of the latter population $(\mathrm{n}=10)$. Both samples were in Hardy-Weinberg equilibrium. This is consistent with the expectations for a population with a relatively high reproductive rate founded by a large number of individuals. We were somewhat concerned that we sampled only a small number of SO-1 offspring and that the structure we described may not have been representative of the entire SO-1 generation. However, the lack of genetic differentiation between SO-1 and the wild SO-P, as well as the large number of polymorphic microsatellite loci identified alleviates these concerns. To the contrary, N-P and N-1 showed significant subdivision, likely reflecting of the small founding population.
Calculating $F_{\text {it }}$ showed significant inbreeding in the entire population and within each of the two separate populations. Each population showed a significant heterozygous deficit, consistent with the population subdivision detected by the $F_{\text {st }}$ analyses. This result likely arose from the physical isolation between the populations and genetic drift within the populations. Further, the low migration rate between San Onofre and Norcasia populations was estimated at four individuals every five generations. This low rate of genetic exchange likely contributed to the isolated genetic structure of the two populations.

However, some unexpected results were found. Inbreeding within samples as measured by $F_{\text {is }}$ was less informative than $F_{\text {st }}$ and $F_{\text {it }}$ of the population's history. Within the San Onofre samples, we observed heterozygous deficit (i.e., inbreeding) not detected in the Norcasia subpopulations. These results are apparently inconsistent with the results of the $F_{\text {st }}$ and $F_{\text {it }}$ analyses. Considered together, SO-P and SO-1 showed four of 10 loci to be in H-W disequilibrium (Table II) and exhibited heterozygosity significantly higher than expected (Table I). To the contrary, N-P and N-1 showed fewer alleles per locus than did the San Onofre populations. Of the loci, $20 \%$ were monomorphic, only one locus was in $\mathrm{H}-\mathrm{W}$ disequilibrium and heterozygosity was close to the expected value (Table I). However, after eight generations of laboratory culture, the N-8 population showed seven loci to be in H-W disequilibrium (Table I) and showed more differences between observed and expected heterozygosity than did SO-11. The differences in $F_{\text {is }}$ estimates between the San Onofre and Norcasia samples may reflect the natural history of the field populations and the founder effects of laboratory colonization. However, the laboratory descendants of the wild Norcasia population $(\mathrm{N}-1$ and $\mathrm{N}-8)$ showed more alleles than did

\section{TABLE II}

Analysis of Hardy-Weinberg equilibrium in Rhodnius pallescens

\begin{tabular}{lcccccc}
\hline \multicolumn{1}{c}{} & \multicolumn{3}{c}{ Sample } \\
\hline Locus & SO-P & SO-1 & SO-11 & N-P & N-1 & N-8 \\
\hline L3 & 0.260313 & 1.000000 & 0.646875 & 0.299063 & 0.118438 & $0.002500^{a}$ \\
L9 & 0.154688 & $0.000937^{a}$ & 0.109375 & 1.000000 & 0.656563 & $0.000000^{a}$ \\
L13 & $0.000000^{a}$ & 0.008750 & 0.027187 & 1.000000 & 0.110000 & $0.000000^{a}$ \\
L17 & $0.000000^{a}$ & 0.105625 & 0.838750 & 0.115000 & 0.029375 & 1.000000 \\
L25 & 0.516250 & 0.014687 & $0.000000^{a}$ & 1.000000 & $0.001875^{a}$ & $0.000313^{a}$ \\
L33 & 0.359063 & 0.104688 & 0.176563 & 1.000000 & 1.000000 & 0.018437 \\
L43 & $0.000313^{a}$ & 0.671875 & $0.000000^{a}$ & 1.000000 & 0.341875 & 0.936875 \\
L47 & 0.137500 & 1.000000 & 0.246875 & 1.000000 & 0.005938 & $0.000625^{a}$ \\
L50 & 0.005000 & 0.381250 & 0.772500 & 0.310312 & 0.013125 & $0.000000^{a}$ \\
L58 & 0.950625 & 0.830313 & 0.667813 & 1.000000 & 0.288438 & $0.000000^{a}$ \\
\hline
\end{tabular}

probabilities from Fisher's exact test per locus and samples. $a$ : significant differences after Bonferroni correction $(\mathrm{p}<0.005)$. N-P: parental (sylvatic) Norcasia; N-1: 1st-generation filial Norcasia; N-8: 7th-8th-generation filial Norcasia; SO-P: parental (sylvatic) San Onofre; SO-1: 1st-generation filial San Onofre; SO-11: 10th-11th-generation filial San Onofre. 
TABLE III

Genetic structuring of Rhodnius pallescens samples as estimated by $F_{\text {st }}$ values

\begin{tabular}{lcc}
\hline & \multicolumn{2}{c}{ Population } \\
\cline { 2 - 3 } Generations & Norcasia & San Onofre \\
\hline P-1-8/11 & 0.073518 & 0.067181 \\
P-1 & $0.100600-0.032097)$ & $(0.109786-0.025776)$ \\
& 0.116726 & 0.018041 \\
P-8/11 & $0.168508-0.037333)$ & $(0.049430$ to -0.008301$)$ \\
& $(0.272060-0.035652)$ & $(0.114775-0.027059)$ \\
$1-8 / 11$ & 0.033365 & 0.094258 \\
& $(0.076277-0.001097)$ & $(0.162066-0.029014)$ \\
\hline
\end{tabular}

confidence intervals, calculated from bootstraps based on 1,000 replications, are indicated in brackets. Significant $F_{\text {st }}$ values do not include zero in the respective confidence interval. P: parental (sylvatic) sample; 1: 1st-generation filial sample; 8: 7th-8th-generation filial sample; 11: 10th-11th-generation filial sample.

the wild population (Table I). There is no clear explanation for this increase, but the excess of homozygosity suggests that null alleles may have played a role in this result. However, our results did not support this hypothesis because inbreeding within the Norcasia samples $\left(F_{\text {is }}\right)$ was not significant.

We propose several alternative explanations for this result. First, the DNA extracted from the N-P specimens may have been damaged, artificially generating null alleles in these samples. This explanation is unlikely, however, as not all microsatellite loci amplified from the same DNA template showed null alleles. Alternatively, problems with allelic scoring could have produced "allelic dropouts". The explanation also seems improbable considering the chosen method of allelic scoring: allele sizes were calculated using an ABI Prism MT310 Genetic Analyzer and representative samples were sent to Macrogen-Korea for cross-validation. Instead, "missing alleles" could have been present in the N-P population, but only in the three founders (not genotyped). This possibility cannot be confirmed and it would not explain the increase in the number of alleles from N-1 to N-8. The well known problem of laboratory colonies contaminated with bugs from other colonies. We have been conscious of this risk and a trained technician routinely applied protocols to avoid such contamination. Finally, the progressive increase in the number of alleles between N-P, $\mathrm{N}-1$ and N-8 could have been caused by demographic effects which produced marked changes in allele frequencies and these changes could have led to differential sampling probabilities for some alleles across generations. This is a very rare but possible event, but we do not presently have the means to confirm this possibility. The above mentioned hypotheses are not mutually exclusive and further studies will further elucidate our results.
Our results strongly suggest that laboratory colonies have been impacted by strong genetic drift followed by expansive population growth under laboratory conditions. Over multiple generations, these populations accumulated variability to reach Hardy-Weinberg equilibrium, but retained a genetic structure distinct that of field populations. The amount of time required to reach Hardy-Weinberg equilibrium is closely related to the number of founders and the number of generations since colonization. A colony founded by a large number of individuals will require few generations to reach equilibrium and indeed, we observed that the SO laboratory colony, founded by a large number of individuals, had reached equilibrium after only a few generations. Laboratory colonies can be used as representatives of wild populations. However, our results emphasize the need for caution in analyzing laboratory colonies. We recommend that artificial colonies be founded by the largest possible number of founders and that natural ecotopes be periodically introduced to the colony to help maintain the original genetic population variability and structure.

Triatomine adaptation to human dwellings may similarly pass through the founder effects seen in laboratory colonies if gene flow is absent or restricted (Schofield et al. 1999). An extensive study throughout Venezuela using 10 polymorphic microsatellite loci did not reveal subdivision between sylvatic and domestic ecotopes ( $F_{\text {st }}$ values were not significant), indicative of active bidirectional gene flow (Fitzpatrick et al. 2008). However geographic subdivisions were detected in some areas, suggesting genetic drift and isolation between populations. The population heterogeneity was more pronounced within the state of Portuguesa (11\% population variation) than in the state of Barinas (3\% population variation). The state of Barinas is more mountainous, which may favour greater population isolation (Fitzpatrick et al. 2008). Harry et al. (2008) expressed concern regarding the use of laboratory strains of $R$. prolixus, because genetic drift resulting from a drastic decrease of the effective size (i.e., a bottleneck) or inbreeding resulting from artificial selection would limit polymorphism. Harry et al. (2008) showed all loci to be polymorphic, leading the authors to conclude that "even tested on laboratory strains, isolated microsatellites seem good candidates for fine-scale population genetic studies on natural populations in which a higher polymorphism is expected". However, our results indicate that although laboratory strains can show high genetic variability, the population structure of laboratory colonies can be very different from that of field populations.

In conclusion, we demonstrated that DNA microsatellite profiles differ significantly between laboratory and wild insect populations. Our results will be useful in monitoring $R$. pallescens invasion of human dwellings and for distinguishing insects recently introduced to artificial dwellings from well-established domestic colonies.

\section{ACKNOWLEDGMENTS}

To reviewers who helped to greatly improve the manuscript. 


\section{REFERENCES}

Abad-Franch F 2003. The ecology and genetics of Chagas disease vectors in Ecuador, with emphasis on Rhodnius ecuadoriensis (Triatominae), PhD Thesis, London School of Hygiene and Tropical Medicine Library, London, 411 pp.

Barton NH, Slatkin M 1986. A quasi-equilibrium theory of the distribution of rare alleles in a subdivided population. Heredity 56: 409-415.

Borges EC, Dujardin JP, Schofield CJ, Romanha AJ, Diotaiuti L 2005. Dynamics between sylvatic, peridomestic and domestic populations of Triatoma brasiliensis (Hemiptera: Reduviidae) in Ceará State, Northeastern Brazil. Acta Tropica 93: 119-126.

Calzada J, Pineda V, Montalvo E, Alvarez D, Santamaría AM, Samudio F, Bayard V, Cáceres L, Saldaña A 2006. Human trypanosome infection and the presence of intradomicile Rhodnius pallescens in the western border of the Panama Canal. Am J Trop Med Hyg 74: 762-765.

Caro-Riaño H, Jaramillo N, Dujardin JP 2009. Growth changes in Rhodnius pallescens under simulated domestic and sylvatic conditions. Infect Genet Evol 9: 162-168.

Catalá SS, Maida DM, Caro-Riaño H, Jaramillo N, Moreno J 2004. Changes associated with laboratory rearing in antennal sensilla patterns of Triatoma infestans, Rhodnius prolixus and Rhodnius pallescens (Hemiptera: Reduviidae, Triatominae). Mem Inst Oswaldo Cruz 99: 25-30.

Chávez T, Moreno J, Dujardin JP 1999. Isoenzyme electrophoresis of Rhodnius species: a phenetic approach to relationships within the genus. Ann Trop Med Parasitol 93: 299-307.

Dlugosch KM, Parker IM 2008. Founding events in species invasions: genetic variation, adaptive evolution and the role of multiple introductions. Mol Ecol 17: 431-449.

Dujardin JP 1998. Population genetics and the natural history of domestication in Triatominae. Mem Inst Oswaldo Cruz 93 (Suppl. II): 34-36.

Dujardin JP, Bermúdez H, Casini C, Schofield CJ, Tibayrenc M 1997a. Metric differences between silvatic and domestic Triatoma infestans (Heteroptera: Reduviidae) in Bolivia. J Med Entomol 34: 544-551.

Dujardin JP, Bermúdez H, Gianella A, Cardozo L, Ramos E, Saravia R, Quiroz K, Forgues G, Carazas R, Hervas D, Chávez T, Machane M, Martínez E, Torrez M 1999a. Uso de marcadores genéticos en la vigilancia entomológica de la enfermedad de Chagas. In JRA Cassab, F Noireau, G Guillén, Chagas: la enfermedad en Bolivia, conocimientos científicos al inicio del programa de control (1998-2002), Ediciones gráficas E. G., La Paz, p. 157-159.

Dujardin JP, Bermúdez H, Schofield CJ 1997b. The use of morphometrics in entomological surveillance of sylvatic foci of Triatoma infestans in Bolivia. Acta Trop 66: 145-153.

Dujardin JP, Chávez T, Machane M, Solis S 1999b. Size, shape and genetics. Sexual dimorphism and environment. In CJ Schofield, C Ponce, Proceedings of the Second International Workshop on Population Biology and Control of Triatominae, Tegucigalpa, Honduras, INDRE, México, p. 53-62.

Dujardin JP, Panzera P, Schofield CJ 1999c. Triatominae as a model of morphological plasticity under ecological pressure. Mem Inst Oswaldo Cruz 94 (Suppl. I): 223-228.

Dujardin JP, Steindel M, Chávez T, Machane M, Schofield C 1999d. Changes in the sexual dimorphism of Triatominae in the transi- tion from natural to artificial habitats. Mem Inst Oswaldo Cruz 94: 565-569.

Fisher RA 1922. On the interpretation of $\chi 2$ from contingency tables and the calculation of P. $J$ R Stat Soc 85: 87-94.

Fitzpatrick S, Feliciangeli MD, Sanchez-Martin MJ, Monteiro FA, Miles MA 2008. Molecular genetics reveal that sylvatic Rhodnius prolixus do colonise rural houses. PLoS Negl Trop Dis 2: e210.

Gómez-Palacio A, Jaramillo-Ocampo N, Triana-Chávez O, Saldaña A, Calzada J, Pérez R, Panzera F 2008. Chromosome variability in the Chagas disease vector Rhodnius pallescens (Hemiptera, Reduviidae, Rhodniini). Mem Inst Oswaldo Cruz 103: 160-164.

Guhl F, Aguilera G, Pinto N, Vergara D 2007. Updated geographical distribution and ecoepidemiology of the triatomine fauna (Reduviidae: Triatominae) in Colombia. Biomédica 27 (Suppl. 1): 143-162.

Harry M, Poyet G, Romaña CA, Solignac M 1998. Isolation and characterization of microsatellite markers in the bloodsucking bug Rhodnius pallescens (Heteroptera, Reduviidae). Mol Ecol 7: 1784-1786

Holm S 1979. A simple sequentially rejective multiple test procedure. Scan J Stat 6: 65-70.

Jaramillo N, Arboleda-Sánchez S, Chaverra Ch, Caro-Riaño $\mathrm{H}$, Gómez-Palacio A, Gómez-Sucerquia L, Saldaña A, Calzada J, Cáceres L 2009. Rhodnius pallescens Barber, 1932 (Hemiptera: Reduviidae): una comparación de las poblaciones Colombianas y Panameñas, basada en su ecología, epidemiología, morfometría y biología molecular. In C Corredor, F Guhl, C Duque, Tendencias y futuro de la investigación en Parasitología y en Productos Naturales (Memorias del Seminario Internacional ACOFACIENACCEFYN, Agosto 4-7 de 2008, Universidad de los Andes), Editorial Guadalupe, Bogotá, p. 113-137.

Jaramillo N, Calle D, Caro-Riaño H, Calle J, Ortega-Barría E 2002. Diferencias morfométricas asociadas a la distribución geográfica de Rhodnius pallescens provenientes de siete localidades de Colombia y Panamá. In OPS/OMS, Iniciativa de los países de Centro América para la interrupción de la transmisión vectorial y transfusional de la Enfermedad de Chagas. Taller técnico de estudio sobre Rhodnius pallescens, su vigilancia y control, Panamá, OPS/DPC/CD/273/03, Panama, p. 15-23.

Jaramillo N, Schofield CJ, Gorla D, Caro-Riaño H, Moreno J, Mejía E, Dujardin JP 2000. The role of Rhodnius pallescens as a vector of Chagas disease in Colombia and Panama. Res Rev Parasitol 60: 75-82.

Jurberg G, Rangel EF 1984. Ciclo biológico de Rhodnius pallescens Barber, 1932 (Hemiptera Reduviidae, Triatominae) em laboratorio. Mem Inst Oswaldo Cruz 79: 303-308.

Lewis PO, Zaykin D 2001. Genetic Data Analysis: Computer program for the analysis of allelic data. Version 1.0 (d16c). Available from: http://lewis.eeb.uconn.edu/lewishome/software.html.

López G, Moreno J 1995. Genetic variability and differentiation between populations of Rhodnius prolixus and $R$. pallescens, vectors of Chagas desease in Colombia. Mem Inst Oswaldo Cruz 90: 353-357.

Miller SA, Dykes DD, Polesky HF 1988. A simple salting out procedure for extracting DNA from human nucleated cells. Nucleic Acid Res 16: 1215.

Nei M 1978. Estimation of average heterozygosity and genetic distance from a small number of individuals. Genetics 89: 583-590.

Peakall R, Smouse PE 2006. GENALEX 6: genetic analysis in Excel. Population genetic software for teaching and research. Mol Ecol Notes 6: 288-295. 
Raymond M, Rousset F 1995. GENEPOP (version 1.2): population genetics software for exact tests and ecumenicism. $J$ Heredity 86: 248-249.

Schofield CJ 1994. Triatominae. Biología y control, Eurocommunica publications, UK, $77 \mathrm{pp}$.

Schofield CJ, Diotaiuti L, Dujardin JP 1999. The process of domestication in Triatominae. Mem Inst Oswaldo Cruz 94: 375-378.

Sousa O 2002. La importancia de Rhodnius pallescens en la enfermedad de Chagas en Panamá. In OPS/OMS, Iniciativa de los países de Centro América para la interrupción de la transmisión vectorial y transfusional de la Enfermedad de Chagas. Taller técnico de estudio sobre Rhodnius pallescens, su vigilancia y control, Panamá, OPS/DPC/CD/273/03, Panama, p. 12-14.

Weir B, Cockerham C 1984. Estimating F-statistics for the analysis of population structure. Evolution 38: 1358-1370.

Zeledón R, Marín F, Calvo N, Lugo E, Valle S 2006. Distribution and ecological aspects of Rhodnius pallescens in Costa Rica and Nicaragua and their epidemiological implications. Mem Inst Oswaldo Cruz 101: 75-79. 